\title{
NUTRITION PROBLEMS AND PROGRAMS IN TAIWAN
}

\author{
KUNG-PEI CHEN \\ Institute of Public Health, College of Medicine, National \\ Taiwan University, Taipei, Taiwan, China
}

\section{NUTRITION PROBLEMS}

The Republic of China has moved forward tremendously during the past 15 years through land-reform, multiple-crops of land utilization, light industry development, and overall transportation network. The people in Taiwan are enjoying relatively high standard of living with per capita income of US $\$ 250$ and low death rate of 5.4 in 1965 . But still there are many nutritional problems remaining to be solved during the process of modernization. The followings are some examples of nutritional problems prevailing in Taiwan.

\section{Age-specific Death Rate of Young Children}

Table 1 shows that the age-specific death rate of young children 1 to 4 years old in Taiwan in 1958 was six times as high as that of U.S.A. and 3 times that of Japan. The result indicates the need of special health care of the neglected children concerning prevention of infection and malnutrition.

\section{Causes of Death in Young Children}

Table 2 indicates that the majorities of five leading causes of death of infants and children aged 1-4 years in 1965 are infectious diseases which are closely related to malnutrition.

\section{Physical Growth}

In comparison of the increment of body weight among American, Japanese and Chinese young children, American boys became superior to Japanese and Chinese boys after the age of six months, while Japanese boys became superior to Chinese after the age of two years (Tab.3) The inferiority of body weight of Chinese young boys may be partially due to inadequate food intake during the weaning

TABLE 1

Age-specific Death Rate of Children in 1958

\begin{tabular}{cccc}
\hline Age & Taiwan $^{b}$ & Japan $^{b}$ & U.S. A. ${ }^{b}$ \\
\hline $0^{a}$ & 30.1 & 29.0 & 28.6 \\
$1-4$ & 6.3 & 2.0 & 1.0 \\
$5-9$ & 1.2 & 0.8 & 0.5 \\
$10-14$ & 0.8 & 0.5 & 0.5 \\
\hline
\end{tabular}

Death rate is expressed as number of death per 1,000 persons.

$a$ The denominator of infant mortality is the number of live birth.

$b$ Demographic Yearbook, 1960. 
TABLE 2

Five Main Causes of Death for Young Chinese Children in 1965

\begin{tabular}{|c|c|c|c|c|}
\hline \multirow{2}{*}{ Order } & \multicolumn{2}{|l|}{ Infant } & \multicolumn{2}{|l|}{ 1-4 year old children } \\
\hline & Cause of Death & D. R. ${ }^{a}$ & Cause of Death & D. R. $a$ \\
\hline 1 & $\begin{array}{l}\text { Other diseases peculiar } \\
\text { to early infancy and } \\
\text { immaturity (B 44) }\end{array}$ & 492.1 & Pneumonia (B 31) & 74.0 \\
\hline 2 & Pneumonia (B 31) & 475.3 & $\begin{array}{l}\text { Gastritis, duodenitis, } \\
\text { enteritis and colitis (B 36) }\end{array}$ & 60.3 \\
\hline 3 & $\begin{array}{l}\text { Infections of the newborn } \\
\text { (B 43) }\end{array}$ & 315.0 & $\begin{array}{l}\text { All other accidents } \\
\text { (BE 48) }\end{array}$ & 56.0 \\
\hline 4 & $\begin{array}{l}\text { Gastritis, duodenitis, } \\
\text { enteritis and colitis (B 36) }\end{array}$ & 295.1 & Measles (B 14) & 39.8 \\
\hline 5 & Bronchitis (B 32) & 203.0 & Bronchitis (B 32) & 27.1 \\
\hline
\end{tabular}

${ }^{a}$ Death rate is expressed as number of death per 100,000 persons.

TABLE 3

Body Weight of Young Boys in Three Countries

(Unit : kg)

\begin{tabular}{cccc}
\hline \hline Age & $\begin{array}{c}\text { Chinese } \\
(1965)\end{array}$ & $\begin{array}{c}\text { Japanese } \\
(1960)\end{array}$ & $\begin{array}{c}\text { American } \\
(1946)\end{array}$ \\
\hline 0 month & 3.21 & $\overline{7}$ & 3.4 \\
1 month & 5.04 & 4.7 & \\
2 months & 5.86 & 5.7 & 5.72 \\
3 months & 6.42 & 6.3 & \\
4 months & 6.95 & 6.8 & 7.58 \\
5 months & 7.44 & 7.4 & \\
6 months & 7.74 & 7.8 & 9.07 \\
7 months & 8.05 & 8.1 & \\
8 months & 8.32 & 8.3 & 10.07 \\
6 months & 8.51 & 8.5 & 12.2 \\
10 months & 8.74 & 8.6 & 12.56 \\
11 months & 8.90 & 8.8 & 14.61 \\
12 months & 9.03 & 9.1 & 16.51 \\
1 years & 10.41 & 10.2 & 1.2 \\
2 years & 11.02 & 13.75 & \\
3 years & 13.69 & 15.48 & \\
4 years & 15.15 & 17.0 & \\
5 years & 16.65 & & \\
\hline
\end{tabular}

Source of information:

1. Shih, S. C., Wu T. H. and Chen, K. P., J. Formosan Med. Assoc. 65, 373 (1966).

2. H. Takemura, Kosei no Shihyō, 8, No. 6: p. 3 (1961).

3. Stuart, H. C., Nerw England J. Med. 234, 666, 693, 732 (1946).

TABLE 4

Age Distribution of Underweighed Children (1965)

\begin{tabular}{cccc}
\hline \hline Age & Number & Percentage & Cumulative \\
\hline Under 6 months & & & per cent \\
$6-2$ months & 4 & 8.0 & 8.0 \\
$1-2$ years & 17 & 34.0 & 42.0 \\
$2-3$ years & 7 & 38.0 & 80.0 \\
$3-6$ years & 3 & 14.0 & 94.0 \\
Total & 50 & 6.0 & 100.0 \\
\hline
\end{tabular}

The data came from Taipei Public Health Teaching and Demonstration Center. 
period. As shown in Table 4, 36 or 72 per cent of 50 underweighed children are in the age of 6 months to 2 years which correspond to weaning period.

\section{Weaning Problems}

As given in Table 5, we have still 25 per cent of the babies starting weaning after the age of one year, and mostly completion of weaning took place in the age of one year. Table 6 shows that during weaning period, 13 to 18 month old boys have the most critical stage of the lowest overall nutrient intake, especially vitamins and calcium. Less intake of calcium, thiamine, and niacin are found through the weaning period of 7 to 24 months of boys. It should be noted that calorie and protein intakes are relatively low at the age of 7 to 18 months.

TABLE 5

Beginning and Completion of Weaning

\begin{tabular}{|c|c|c|c|c|c|c|}
\hline \multirow{3}{*}{ Age } & \multicolumn{6}{|c|}{ Weaning } \\
\hline & \multicolumn{3}{|c|}{ Beginning } & \multicolumn{3}{|c|}{ Completion } \\
\hline & No. & Percentage & Cumulat. & No. & Percentage & Cumulat. \\
\hline & & & per cent & & & per cent \\
\hline Before 6 months & 40 & 7.9 & 7.9 & 24 & 5.2 & 5.2 \\
\hline 6-11 months & 335 & 66.5 & 74.4 & 82 & 18.0 & 23.2 \\
\hline $12-23$ months & 129 & 25.6 & 100.0 & 350 & 76.4 & 99.6 \\
\hline 24 months and above & 0 & 0.0 & - & 2 & 0.4 & 100.0 \\
\hline Total & 504 & 100.0 & & 458 & 100.0 & \\
\hline
\end{tabular}

Source of information: Taiwan Provincial MCH Institute and National Taiwan University Hospital, 1961.

TABLE 6

Per Capita Nutrient Intake in Percentage of Recommended Allowance of 156 Infants

\begin{tabular}{lccc}
\hline \hline Nutrient & 7-12 months & 13-18 months & 19-24 months \\
\hline & & Per cent & \\
Calorie & 40.7 & 46.8 & 87.6 \\
Protein (g) & 64.8 & 54.1 & 107.2 \\
Calcium (g) & 30.4 & 18.2 & 45.9 \\
Iron (mg) & 90.0 & 64.4 & 114.4 \\
Vitamin A (I.U.) & 83.0 & 29.8 & 41.6 \\
Thiamine (mg) & 38.3 & 18.8 & 33.8 \\
Riboflavin (mg) & 80.0 & 21.0 & 24.0 \\
Niacin (mg) & 30.7 & 27.0 & 43.9 \\
Ascorbic acid (mg) & 76.9 & 45.4 & 71.7 \\
\hline
\end{tabular}

Source of information: Taiwan Provincial MCH Institute, Nov. 1961 (unpublished).

\section{Population Growth}

As shown in Table 7, the number of population in Taiwan has become double during the past 18 years with an annual increase of 3 per cent. It is estimated that the population in Taiwan would be double again in 25 years if the annual increase is kept at the same rate of 3 per cent.

On the other hand, the annual natural increase of Japanese is 1.07 per cent and that of Amercian 1.2 per cent. Table 8 shows that production age population occupy only 43 per cent of the total population in Taiwan, while they occupy 56.8 
per cent in Japan. So dependent burden in Taiwan is 131.6 while it is 71.6 in Japan. This fact would influence greatly the economic burden and the living standard of family, community and the nation as a whole.

Table 9 indicates that the high birth rate in Taiwan was mainly due to the continuous child birth at older ages rather than due to early marriage.

TABLE 7

Population Growth in Taiwan ${ }^{a}$

\begin{tabular}{ccccc}
\hline \hline Year & $\begin{array}{c}\text { No. Total } \\
\text { Population } \\
(1,000 \text { unit })\end{array}$ & Birth Rate & Death Rate & $\begin{array}{c}\text { Natural } \\
\text { Increase }\end{array}$ \\
\hline & & $\% \circ$ & $\%$ & $\%$ \\
1947 & 6,495 & 37.12 & 17.58 & 19.54 \\
1952 & 8,128 & 45.88 & 9.72 & 36.16 \\
1957 & 9,690 & 40.75 & 8.33 & 32.42 \\
1962 & 11,512 & 36.79 & 6.63 & 26.82 \\
1965 & 12,628 & 32.20 & 5.38 & 10.70 \\
Japan $^{b}$ & 97,186 & 17.6 & 6.90 & 12.00 \\
(1964) & 189,278 & 21.6 & 9.60 & \\
U.S.A. ${ }^{c}$ & & & & \\
(1963) & & &
\end{tabular}

Source of information:

a PHD, Statistical Abstract for 1965, Taiwan, Rep. of China, 1966.

- Kosei no Shihyō: Special issue, 12, No. 11, Oct. 1965.

c U. N.: Demographic Yearbook, 1965.

TABLE 8

Percentage of Dependent and Production Age Population and Dependency

\begin{tabular}{|c|c|c|c|c|}
\hline \multirow{2}{*}{ Country } & \multicolumn{3}{|c|}{ Age } & \multirow{2}{*}{$\begin{array}{c}\text { Dependency } \\
\text { burden }\end{array}$} \\
\hline & under 19 & $20-64$ & 65 and over & \\
\hline & \multicolumn{4}{|c|}{ per cent } \\
\hline Chinese $^{a}$ & 54.2 & 43.2 & 2.6 & 131.8 \\
\hline$\underset{(1964)}{J^{2}}$ & 37.0 & 56.8 & 6.2 & 71.6 \\
\hline$\underset{(1963)}{\text { American }}{ }^{c}$ & 39.2 & 51.5 & 9.3 & 94.2 \\
\hline
\end{tabular}

a Taiwan Population Studies Center., Demographic Reference, Taiwan, Rep. of China. 1, (1965).

${ }^{b}$ Kosei no Shihyō 12, No. 10 (1965). $\quad$ c U. N., Demographic Yearbook, (1965).

TABLE 9

Age Specific Fertility Rate and Crude Birth Rate in Four Countries (1954)

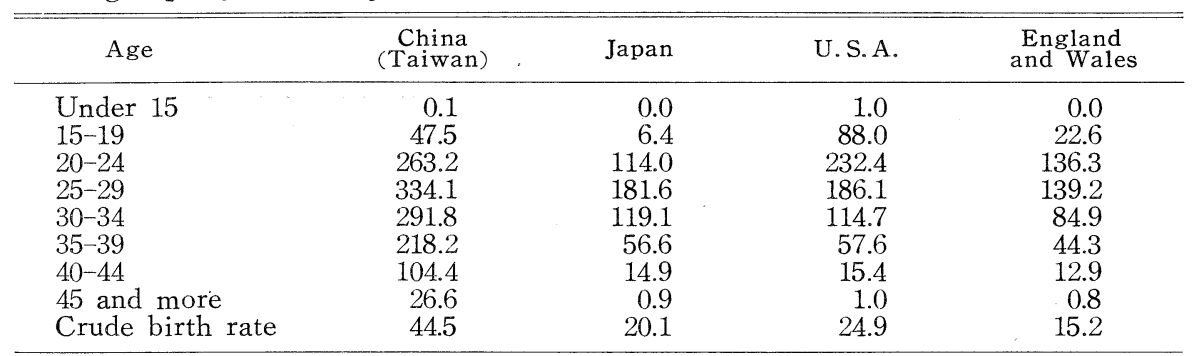

Source of information: Wu, H. Y., J. Formosan Med. Assoc., 58, 589 (1959). 


\section{Endemic Goiter}

Although Taiwan is a small island surrounded by the sea, endemic goiter is quite popular with the average rate of 21.6 per cent of school children surveyed in 342 districts. Nearly a half of the school children living on the hill side have a grade-one goiter while only one out of ten school children has a goiter in the center of municipalities (Table 10).

TABLE 10

Prevalence of Endemic Goiter of School Children in Taiwan (1964-1965)

\begin{tabular}{lcccc}
\hline \hline Topographic area & $\begin{array}{c}\text { No. of } \\
\text { districts }\end{array}$ & $\begin{array}{c}\text { No. children } \\
\text { examined }\end{array}$ & $\begin{array}{c}\text { No. children } \\
\text { with goiter }\end{array}$ & $\begin{array}{c}\text { Goiter } \\
\text { rate }\end{array}$ \\
\hline Rural area (hillside) & 73 & 20,506 & 9,268 & 45.2 \\
Township & 43 & 22,193 & 4,405 & 19.8 \\
Rural area (plain) & 105 & 26,173 & 5,047 & 19.3 \\
Municipal (peripheral) & 19 & 7,706 & 1,173 & 15.2 \\
Aboriginal area & 16 & 1,030 & 148 & 14.4 \\
Seacoast district & 63 & 13,855 & 1,488 & 10.7 \\
Municipal dist. (central) & 23 & 14,797 & 1,374 & 9.3 \\
$\quad$ Total & 342 & 106,260 & 22,903 & 21.6 \\
\hline
\end{tabular}

a Thyroid enlargement with grade I and over according to WHO standard.

Source of data: Chen, K.P. et al, A survey on endemic goiter of school children in Taiwan (unpublished).

\section{Parasite Infestation in Rural Area}

There is a high prevalence of parasite infestation in rural area of Taiwan. According to an investigation done in southern rural area by Hsieh, 57.3, 49.2 and 36.9 per cent of men harbor hookworm, ascaris and trichuris respectively. The infection rates of hookworm are higher at older ages while those of ascaris and trichuris are higher at younger ages.

TABLE 11

Infection Rate (\%) of Parasitic Diseases of Rural People in South Taiwan

\begin{tabular}{|c|c|c|c|c|c|c|}
\hline \multirow{2}{*}{ Age } & \multicolumn{2}{|c|}{ Hookworm } & \multicolumn{2}{|c|}{ Ascaria } & \multicolumn{2}{|c|}{ Trichuris } \\
\hline & Male & Female & Male & Female & Male & Female \\
\hline $0-4$ & 15.8 & 18.8 & 68.5 & 62.8 & 24.1 & 24.6 \\
\hline $5-9$ & 47.7 & 40.0 & 73.8 & 80.2 & 55.0 & 62.7 \\
\hline $10-14$ & 63.8 & 56.0 & 62.2 & 62.1 & 61.6 & 54.9 \\
\hline $15-19$ & 72.4 & 72.4 & 42.5 & 50.0 & 40.4 & 36.7 \\
\hline $20-29$ & 77.0 & 73.3 & 31.8 & 49.0 & 23.0 & 33.6 \\
\hline $30-39$ & 72.3 & 69.3 & 35.1 & 50.1 & 28.8 & 36.1 \\
\hline $40-49$ & 71.4 & 72.3 & 34.5 & 44.1 & 29.8 & 35.0 \\
\hline 50 and more & 68.0 & 63.4 & 31.0 & 36.6 & 27.5 & 30.3 \\
\hline Total & 57.3 & 54.7 & 49.2 & 56.9 & 36.9 & 39.9 \\
\hline
\end{tabular}

Source of data: Hsieh, H.C., J. Formosan Med. Assoc. 64, 138 (1965).

\section{NUTRITION PROGRAMS}

\section{Agricultural Food Production}

As shown in Tab. 12, development of agriculture, such as land reform, water preservance, supply of more chemical fertilizer, seed improvement, agricultural loans 
TABLE 12

Agricultural Food Production in Taiwan 1960 and 1965

\begin{tabular}{lrrr}
\hline $\begin{array}{l}\text { Agricultural } \\
\text { food }\end{array}$ & 1960 & 1965 & $\frac{65-60}{1960} \times 100$ \\
\hline & & & per cent \\
Food Crops & $1,912.0$ & $2,271.7$ & 18.8 \\
Rice & $2,978.7$ & $3,131.1$ & 5.1 \\
Sweet potato & 102.2 & 125.8 & 23.1 \\
Peanut & 52.7 & 65.7 & 24.7 \\
Soybean & 772.7 & 962.8 & 24.6 \\
Vegetables & 338.6 & 915.0 & 170.2 \\
Fruits & & & \\
Live Stock & 171.5 & 217.5 & 27.1 \\
Pork & 3.5 & 5.1 & 54.6 \\
Beef & 0.6 & 0.8 & 33.3 \\
Mutton & 15.9 & 25.8 & 62.3 \\
Poultry & 18.5 & 30.8 & 189.8 \\
Egg & 4.9 & 14.2 & 47.3 \\
Milk & 259.1 & 381.7 & \\
Fishery & & & \\
\end{tabular}

Source of information: Joint Commission on Rural Reconstruction, 1967.

and strengthening of farmer's association have facilitated better yield of food crops. The production of various food crops has increased by over 18 per cent during five years of 1960 to 1965 , except sweet potato. There was great achievement in higher production of fruits with 170.2 per cent increment. These fruits are bananas, pineapples, lemons and tangerines, etc.

The production of live stook also continues to increase. Especially, fishery, poultry, egg and milk productions have increased by 47,62, 67 and 190 per cent respectively.

The higher production of those high valued foods indicates that more animal protein will be supplied to obtain more balanced diet.

2. Taiwan Per Capita Nutrient Availability

In spite of rapid population growth in Taiwan, availability of food energy has

TABLE 13

Taiwan Average Per Caput Nutrient Availabilities

\begin{tabular}{crrr}
\hline \hline Nutrient & 1955 & 1965 & $\frac{65-60}{1955} \times 100$ \\
\hline & & & per cent \\
Food Energy (Cal.) & 2,218 & 2,411 & 8.7 \\
Protein \{ vegetables & 38.85 & 43.62 & 9.5 \\
(g) total & 13.30 & 17.58 & 32.2 \\
Fat (g) & 53.15 & 61.20 & 15.1 \\
Calcium (mg) & 37.17 & 46.66 & 25.5 \\
Iron (mg) & 262.60 & 423.57 & 61.3 \\
Vitamin A & 8.76 & 9.67 & 10.4 \\
Thiamine (mg) & $4,319.80$ & $3,728.60$ & -13.7 \\
Riboflavin (mg) & 1.15 & 1.39 & 20.9 \\
Niacin (mg) & 0.52 & 0.58 & 10.3 \\
Ascorbic acid & 12.07 & 13.88 & 15.0 \\
\end{tabular}

Source of information: Joint Commission on Rural Reconstruction, 1967. 
steadily increased from 2,218 Calories in 1955 to 2,411 Calories in 1965 (Tab. 13). The items of nutrients which have increased by more than 10 per cent during the past ten years are animal protein $(32.2 \%)$, fat $(25.5 \%)$, calcium $(61.3 \%)$, iron $(10.4 \%)$, thiamine $(20.9 \%)$, riboflavin $(10.3 \%)$ and niacin $(15.0 \%)$. The amount of vitamin $\mathrm{A}$ and ascorbic acid available has decreased more than ten per cent because the export of local vegetables and fruits has been promoted gradually in recent years.

\section{School Lunch Program}

The Ministry of Education initiated school lunch pilot project with assistance of AID/USA in 1964 for the purpose of promoting the health condition of school children. 280 primary schools in 1964, 318 in 1966, mostly in underprivileged areas, were selected for this program. AID/USA was asked to supply wheat flour, skimmed milk, vegetable oils, and enriched bulgar. Each student should pay around NT $\$ 15.00$ to 30.00 a month to supplement the purchase of accessary foods, such as vegetables, small fish, meat, nuts, etc. Table 14 shows one of the menu in school lunch and nutritional value. The amount of all nutrients exceeds 40 per

TABLE 14

Menu in School Lunch and Its Nutritional Value

\begin{tabular}{|c|c|c|c|c|c|c|c|c|c|}
\hline \multirow{2}{*}{ Nutrient } & \multirow{2}{*}{ Energy } & \multirow{2}{*}{ Protein } & \multirow{2}{*}{ Calcium } & \multirow{2}{*}{ Iron } & \multicolumn{5}{|c|}{ Vitamin } \\
\hline & & & & & $\mathrm{A}$ & $\mathrm{B}_{1}$ & $\mathrm{~B}_{2}$ & Niacin & $\mathrm{C}$ \\
\hline & Cal & $g$ & $m g$ & $m g$ & $I . U$ & $m g$ & $m g$ & $m g$ & $m g$ \\
\hline $\begin{array}{l}\text { Amount } \\
\text { taken }\end{array}$ & 995.6 & 34.0 & 666.4 & 11.8 & 4,663 & 1.21 & 1.20 & 9.20 & 40.8 \\
\hline $\begin{array}{l}\text { Amount } \\
\text { required }\end{array}$ & 920.0 & 28.0 & 480.0 & 4.8 & 1,800 & 0.56 & 0.72 & 5.60 & 28.0 \\
\hline
\end{tabular}

Menu: Total amount: $450 \mathrm{~g}$.

1. Wheat flour bread; wheat flour $150 \mathrm{~g}$, baking powder $3 \mathrm{~g}$.

2. Fried beancurd and vegetables; dried beancurd $10 \mathrm{~g}$, clery $10 \mathrm{~g}$, carrot $20 \mathrm{~g}$, vegetable oil $6 \mathrm{~g}$.

3. Soup; skin milk $30 \mathrm{~g}$, yeast $5 \mathrm{~g}$, sea weed $10 \mathrm{~g}$, sliced egg $5 \mathrm{~g}$, green vegetables $100 \mathrm{~g}$, enriched bulgar $30 \mathrm{~g}$.

TABLE 15

Effect of School Lunch Progam on Physical Growth and Nutritonal Deficiencies

\begin{tabular}{lcc}
\hline \hline \multicolumn{1}{c}{ Items } & $\begin{array}{c}\text { Project scool } \\
\text { children minus } \\
\text { boys }\end{array}$ & $\begin{array}{c}\text { Control school children } \\
\text { girls }\end{array}$ \\
\hline $\begin{array}{l}\text { Height (cm) } \\
\text { Weight (kg) }\end{array}$ & $0.22 \pm 0.04^{b}$ & $0.11 \pm 0.05^{a}$ \\
$\begin{array}{l}\text { Skinfold (mm) } \\
\text { Angular stomatitis (\%) } \\
\quad(\text { mild) }\end{array}$ & $0.04 \pm 0.04^{a}$ & $0.12 \pm 0.05^{a}$ \\
$\quad \begin{array}{l}\text { Angular stomatitis (\%) } \\
\quad \text { (moderate) }\end{array}$ & $2.90 \pm 1.52^{a}$ & $3.50 \pm 1.39^{a}$ \\
$\begin{array}{l}\text { Endemic goiter with grade I } \\
\text { and over (\%) } \\
\text { Endemic goiter with grade II } \\
\text { and over (\%) }\end{array}$ & $1.60 \pm 1.08^{a}$ & $0.60 \pm 0.80$ \\
\end{tabular}

$a 5 \%$ level of significance. $\quad b 1 \%$ level of significance.

Source of data: Chen, Kung-pei and Wu, Tsung-hsien: The Third Report on the Evaluation of School Lunch Program in Taiwan, Dec, 1966 (mimeographed)。 
cent of nutritional request for school children aged 10 to 12 years. To avoid monotony and increase appetite, the menu is changed every day within a week.

As shown in Table 15, the increment of height, weight, and skin fold of project school children were much greater than those of control school children during recent two years' observation. The reduction rate of some nutritional deficiencies, such as angular stomatitis and endemic goiter were higher in project schools than in control schools.

\section{Nutrition Program at Health Station}

Milk Supply Station Program - To improve nutritional status of mothers and children, and to encourage a habit of drinking cow's milk, 25 milk supply stations were set up in 1961, since then gradually increased to 196 stations over the island in $1966.30 \mathrm{~g}$ of skimmed milk powder per capita provided by UNICEF is prepared every day to make $300 \mathrm{ml}$. milk. Each station is facilitated to supply 200 pregnant or lactating mothers and preschool children. In 1966, 39,200 of them were benefited from this service.

Nutritional Guidance at Well Baby Clinic-Nutritional guidance is given by public health nurses at well baby clinic which is carried out once or twice a week in 361 health stations all over the island. A certain amount of whole milk or skimmed milk powder are given to malnourished babies, if needed. Table 16 shows that the incidence of underweighed children in one demonstration health station at Taipei City has gradually gone down from 10 per cent in 1960 to 3.6 per cent in 1965 .

TABLE 16

Incidence of Underweighed Children at Child Health Conference (Taipei Public Health Teaching and Demonstration Center)

\begin{tabular}{cccc}
\hline \hline Year & $\begin{array}{c}\text { No. of new cases } \\
\text { at the CHC }\end{array}$ & $\begin{array}{c}\text { No. of underweighed } \\
\text { children }\end{array}$ & $\begin{array}{c}\text { Incidence of } \\
\text { underweight }\end{array}$ \\
\hline & & & per cent \\
1960 & 1,301 & 132 & 10.15 \\
1961 & 1,332 & 129 & 9.68 \\
1962 & 1,373 & 104 & 7.57 \\
1963 & 1,399 & 94 & 6.72 \\
1964 & 1,552 & 71 & 4.52 \\
Total & 1,399 & 50 & 3.57 \\
& 8,356 & 580 & 6.94
\end{tabular}

Source of data: Annual Report of Taipei Public Health Teaching and Demonstration Center, Taipei, 1955.

\section{Family Planning Action Program}

The government health organization incorporated family planning into the regular maternal and child health program since 1959 through conventional contraceptive methods.

The island-wide family planning program with intra-uterine loop was started in January 1964. During the past three years by the end of 1966, 257,095 women have accepted loop insertion which reached 95.2 per cent of the target number and corresponded to 16.7 per cent of the total married women 20-44 years old. (Table 17) 
TABLE 17

Numbers of Intrauterine Loop Acceptors in Taiwan by Calender Year

\begin{tabular}{cccc}
\hline \hline Year & $\begin{array}{c}\text { No. of loop } \\
\text { acceptors }\end{array}$ & $\begin{array}{c}\text { Target of loop } \\
\text { insertion }\end{array}$ & Percentage \\
\hline 1964 & 46,600 & 50,000 & 93.2 \\
1965 & 99,253 & 100,000 & 99.3 \\
1966 & 111,242 & 120,000 & 92.7 \\
Total & $257,095^{\alpha}$ & 270,000 & 95.2 \\
\hline
\end{tabular}

a The total number of loop acceptors corresponds to 16.7 per cent of the total married women $20-44$ yeas old.

\section{Endemic Goiter Control Program}

A pilot project on endemic goiter prevention with iodized salt containing 100 ppm iodine was initiated in 1959 by Institute of Public Health, National Taiwan University with the financial assistance of JCRR. During the experimental period of three years, the prevalence rate of endemic goiter in experimental areas reduced remarkably. Another project was started in 1965 by Provincial Health Department with the help of UNICEF to cover one million population in four goiter endemic counties. The level of iodate content in this project was $1: 30,000$ (33 ppm iodate).

As shown in Table 18, the prevalence rate of endemic goiter in school children has reduced by nearly 50 per cent for the thyroid enlargement with grade I and by 73 per cent for grade II and over during two years' administration of iodized salt. As a result of this successful pilot project, a island-wide mass campaign was started in January 1967.

TABLE 18

Effect of Salt Iodization on Endemic Goiter in Four Counties, Taiwan

\begin{tabular}{|c|c|c|c|c|c|c|}
\hline \multirow{2}{*}{ County } & \multirow{2}{*}{ Period } & \multirow{2}{*}{$\begin{array}{l}\text { No. children } \\
\text { examined }\end{array}$} & \multicolumn{2}{|c|}{ Goiter Grade I and over } & \multicolumn{2}{|c|}{ Goiter Grade II and over } \\
\hline & & & No. & Percentage & No. & Percentage \\
\hline \multirow{2}{*}{$\begin{array}{l}\text { Nantou } \\
\text { County }\end{array}$} & $\begin{array}{l}\text { Before } \\
\text { iodization }\end{array}$ & 7,284 & 4,604 & 63.2 & 1,311 & 18.0 \\
\hline & $\begin{array}{l}\text { Aftere } \\
\text { iodization }\end{array}$ & 8,057 & 2,271 & 28.2 & 240 & 3.0 \\
\hline \multirow{2}{*}{$\begin{array}{l}\text { Hsinchu } \\
\text { County }\end{array}$} & $\begin{array}{l}\text { Before } \\
\text { iodization }\end{array}$ & 8,589 & 4,137 & 48.2 & 661 & 7.7 \\
\hline & $\begin{array}{l}\text { Aftere } \\
\text { iodization }\end{array}$ & 8,345 & 1,508 & 18.1 & 128 & 1.5 \\
\hline \multirow{2}{*}{$\begin{array}{l}\text { Miaoli } \\
\text { County }\end{array}$} & $\begin{array}{l}\text { Before } \\
\text { iodization }\end{array}$ & 8,295 & 3,058 & 36.9 & 394 & 4.8 \\
\hline & $\begin{array}{l}\text { Aftere } \\
\text { iodization }\end{array}$ & 8,265 & 1,869 & 22.5 & 282 & 3.4 \\
\hline \multirow{2}{*}{$\begin{array}{l}\text { 'Taichung } \\
\text { County }\end{array}$} & $\begin{array}{l}\text { Before } \\
\text { iodization }\end{array}$ & 10,173 & 2,466 & 24.2 & 274 & 2.7 \\
\hline & $\begin{array}{l}\text { Aftere } \\
\text { iodization }\end{array}$ & 10,658 & 1,874 & 17.6 & 109 & 1.0 \\
\hline \multirow{2}{*}{ Total } & $\begin{array}{l}\text { Before } \\
\text { iodization }\end{array}$ & 34,341 & 14,265 & 41.5 & 2,640 & 7.7 \\
\hline & $\begin{array}{l}\text { Aftere } \\
\text { iodization }\end{array}$ & 35,325 & 7,522 & 21.3 & 759 & 2.1 \\
\hline
\end{tabular}




\section{DISCUSSION}

Dr. K. Okuda: Having enough fish along the coast, the incidence of goiter in Formosa seems still high compared with Japan. How do you account for that?

Dr. Kung-Pei Chen : The prevalence of endemic goiter is the highest in school children living on the hillside, while school children on the seacoast has the second lowest rate of goiter. Although fish is consumed popularly as one of major animal protein souces, the people on the hillside consume less fish or the iodine content in fish may not be sufficient to prevent the occurrence of endemic goiter.

Dr. A. Valyasevi: How severe is the goiter problem seen in Taiwan, especially in children?

Dr. Kung-Pei Chen : Most of school children with endemic goiter have no symptoms. There are very few cases of cretinism and congenital deafmutism. No evidences of causing mental retardation are found. Contrarily, we found that those school children with endemic goiter are taller and heavier than shool children without goiter. It was also found from our pilot project of goiter prevention with iodized salt that the reduction rate of endemic goiter for those children who grew faster was lower than that of the children who grew slower. These facts let us think that endemic goiter is a compensational manifestation for meeting physiological requirement of thyroxine in individual child.

Dr. E. Hamamoto: I am very glad to hear the mortality of new-born infants is quite the same in Taiwan as in Japan, but that of 2-3 year old children is much higher in Taiwan. In Japan we have already completed many kinds of pertussis, vaccination. For example, diphtheria, pertussis, variola, tuberculosis, polio, encephalitis and even measles. I think it will be very effective to decrease the mortality of $2-3$ year old children.

Dr. Kung-Pei Chen: I hope so. The death rate of children 1-4 years old is a very good health indicator to show the overall development of a country. The high death rate in Taiwan does not mean that we do not have those effective vaccines as mentioned by Dr. Hamamoto. But it is a public health problem concerning how to apply practically and comprehensively to all the children needed for immunization. That involves organization, staffing, health concepts of mothers to accept immunization, financial strength to provide preventive and curative facilities for those healthy and sick children, and environmental sanitation for gastritis, colitis and diarrhea. So this health index represents the strength of a country in terms of economic conditions, educational levels, and medical care and public health availabilities.

Dr. H. Yoshimura: What kind of food is utilized as the main souce of animal protein?

Dr. Kung-Pei Chen : Mainly pork, fish, duck egg, occasionaly chicken. Beef is less often used. The production of cow's milk has increased tremendously in recent years. But it is still not popular as daily meal, consumed only for patients, and children, but not for adults.

Dr. A. Valyasevi: What has been changed in the dietary habits of the infants and preschool children?

Dr. Kung-Pei Chen: For infants as artificial feeding cow's fresh milk and milk powder become popular even in rural area instead of using condensed milk or rice gruel as was the case before. Weaning is a big problem because of lack of protein-rich baby food. There are some trials to use soy bean milk and wheat cake enriched with vitamins, yeast, iron and minerals. Nutritional guidance has been strengthened to add fish flour, meat flour, egg, vegetable extract, ground liver emulsion to rice gruel at an early weaning period. 